\title{
Systemic Risk in the Insurance Sector: A Review of Current Assessment Approaches
}

\author{
Andreas A. Jobst \\ European Department, International Monetary Fund (IMF), 700 19th Street NW, District of Columbia, \\ Washington 20431, U.S.A. \\ E-mail: ajobst@imf.org
}

The following article reviews the recent regulatory efforts in defining systemic risk in the insurance sector and the designation of systemically important insurers. Although current evidence suggests that core insurance activities are unlikely to cause or propagate systemic risk, the characteristics and business models of insurance firms vary by country and might require a more nuanced examination, with a particular focus on non-traditional and/or non-insurance activities. The article also includes the assessment of identified vulnerabilities from liquidity risk in the context of the Bermuda market, which provides valuable insights into systemic risk analysis in the domestic context of an insurance market dominated by non-life underwriting.

The Geneva Papers (2014) 39, 440-470. doi:10.1057/gpp.2013.7

Keywords: financial crisis; insurance sector; macroprudential; systemic risk; SIFI; G-SII

Article submitted 28 May 2012; accepted 6 February 2013; published online July 2014

\section{Introduction}

In the wake of the global financial crisis, there has been increased focus on systemic risk as an essential element of macroprudential policy and surveillance (MPS). ${ }^{1}$ MPS aims to limit, mitigate or reduce systemic risk, thereby minimising the incidence and impact of disruptions in the provision of key financial services due to an impairment of all or parts of the financial system that can have adverse consequences for the functioning of the real economy (and broader implications for economic growth).

The identification of SIFIs is a crucial element of systemic risk analysis within MPS. Systemic risk refers to individual or collective financial arrangements - both institutional and market-based - that could either lead directly to system-wide distress in the financial sector and/or significantly amplify its consequences (with adverse effects on other sectors, in particular, capital formation in the real economy). The potential emergence of systemic risk and its impact on financial stability

\footnotetext{
${ }^{1}$ See BIS (2011) and IMF (2011b) for an overview of current theoretical and empirical work on macroprudential policy and regulation, IMF (2013) for the latest guidance on macroprudential policy, and IAIS (2013d) with reference to MPS for insurance. In a recent progress report to the G20 (FSB/IMF/BIS, 2011b), which followed an earlier update on macroprudential policies (FSB/IMF/BIS, 2011a), the FSB takes stock of the development of governance structures that facilitate the identification and monitoring of systemic risk. See also IMF (2011a) for more insights on the governance issues surrounding macroprudential policies and IMF (2011a) for a more empirically focused review of macroprudential surveillance.
} 
is significantly influenced by institutions whose disorderly failure, because of their size, complexity and systemic interconnectedness, would cause significant disruption to the financial system and economic activity. ${ }^{2}$ A material financial distress at such a systemically important financial institution (SIFI), related to its nature, scope, size, scale, concentration, interconnectedness, or the mix of its activities, ${ }^{3}$ can adversely affect financial stability due to the spillover effects of their actions on the financial system and the wider economy.

Policy-makers have recognised the need for enhanced regulatory and supervisory requirements for SIFIs in response to concerns over the moral hazard risks arising from large and highly integrated financial institutions that are regarded as too important to fail. In 2009, the FSB mandated both the Basel Committee on Banking Supervision (BCBS) and the International Association of Insurance Supervisors (IAIS) to develop a methodology to assess the systemic importance of banks and insurance firms, respectively. The commonly accepted definition of SIFIs ${ }^{4}$ has placed also non-bank financial institutions squarely within the scope of any systemic risk regime, including systemically relevant insurance companies. Although the $\mathrm{BCBS}^{5}$ has already designed an indicator-based approach for the identification of global systemically important banks, so-called "G-SIBs", similar efforts are nearing completion for the identification of systemically relevant non-banking activities (with the most challenging policy agenda still lying ahead in the area of systemic risk within shadow banking). In July 2013, after one year of public consultation, the IAIS 6 - in coordination with the FSB - published its final version of an initial assessment methodology for the identification of globally active, systemically important insurance firms (G-SIIs) together with a draft proposal of policy measures for designated firms, ${ }^{7}$ including enhanced supervision, effective recovery and resolution, and capital requirements. Most recently, the $\mathrm{FSB}^{8}{ }^{8}$ in consultation with the International Organization of Securities Commissions (IOSCO), also proposed assessment methodologies for identifying non-bank, non-insurer global systemically important financial institutions (NBNI G-SIFIs), which covers finance companies, market intermediaries (securities broker-dealers) and investment funds.

The designation of SIFIs in the insurance sector has attracted considerable attention. The weighted indicator-based approach for G-SIIs is similar in concept to that used to identify G-SIBs, but also introduces additional indicators that are germane to insurance activities. In addition, the IAIS has created working parties for the development of both basic capital requirements (BCR) for purposes of general loss absorbency (LA) and higher loss absorption (HLA) capacity requirements for G-SIIs by the end of 2014 and 2015, respectively, which are likely to be informed by G-SII assessment methodology. The increased supervisory focus on systemic risk has already elevated identification of systemically important activities to the level of standard insurance principles in 2011. The new ICP 24 (Macroprudential Surveillance and Insurance Supervision) charges supervisors with the monitoring of vulnerabilities in the financial system and underlying trends within the insurance sector,

\footnotetext{
${ }^{2}$ FSB/IMF/BIS (2009); FSB (2010, 2012).

${ }^{3}$ FSOC (2011).

${ }^{4}$ FSB/IMF/BIS (2009); FSB (2010).

5 BCBS $(2011,2013)$.

${ }^{6}$ IAIS (2012c, 2013c).

${ }^{7}$ IAIS (2012a, 2013c).

${ }^{8}$ FSB (2014).
} 
aimed at identifying and mitigating systemic risk that might negatively affect the risk profile of insurers. ${ }^{9}$

This article reviews the past and current discussion on systemically relevant activities in the insurance industry and examines the plausibility of existing approaches in a theoretical and practical context. Any approach aimed at measuring systemic risk across different areas of financial activity consistently and effectively needs to be flexible enough to take into account that the various types of financial institutions perform different functions within the financial system. Although core principles used to determine systemic relevance should be applied universally, the designation of systemically important insurers would heed the distinct characteristics of insurance business models and the extent to which certain firms engage in activities that are, or could become, systemically relevant. In this regard, the article establishes a common understanding of whether some identified vulnerabilities from nontraditional and/or non-insurance (NTNI) activities (especially in the area of liquidity risk) are relevant to the (re)insurance sector in Bermuda for the identification of systemic riskwithout proposing new prudential standards guiding their supervisory treatment.

The article is structured as follows. After highlighting the differences between the business models of banks and insurance companies, which influence the design and implementation of macroprudential tools to limit systemic risk, the article reviews the scope of systemically important activities in the insurance sector and the identification of systemically important insurance firms (Section "systemic risk measurement and its relevance in the insurance sector"). Based on industry proposals and supervisory discussions that informed the current consultation on G-SIIs, the subsequent section examines whether some insurance activities that have generally been considered systemically relevant on a global scale also pose similar risks for the (re)insurance industry in Bermuda, which is largely focused on non-life underwriting activities. The latter section introduces the proposed assessment methodology for G-SIIs and provides initial considerations regarding its implications for the consistent treatment of systemic risk in financial sector regulation. The final section concludes by highlighting existing challenges and provides a forward-looking perspective on supervisory initiatives in this regard.

\section{Systemic risk measurement and its relevance in the insurance sector}

\section{General principles of systemic risk measurement}

Despite many methodological and empirical approaches aimed at the identification and measurement of systemic risk, there is still no consistent theory of regulating and supervising systemically important activity. Ideally, systemic risk measures should support, or be linked to, MPS objectives, by providing information on the build-up of system-wide vulnerabilities in both the time and cross-sectional dimensions with an acceptable level of accuracy and forecasting power for financial instability.

The existing approaches can be broadly distinguished based on their conceptual underpinnings regarding the sources and risk transmission that would render a financial institution systemically relevant. There are three general approaches: (i) a particular activity causes a firm to fail and imposes marginal distress on the system due to the nature, scope, size, scale,

\footnotetext{
${ }^{9}$ IAIS (2011b).
} 
concentration or connectedness of its activities with other financial institutions ("contribution approach"), or a firm either (ii) absorbs ("participation approach") or (iii) amplifies the shock ("participation-contribution approach") from the scope and/or magnitude of impact of one or more negative shocks to commonly held exposures to a particular sector, country, interest rate and/or currency due to their types of business models, risk profiles and/or performance characteristics. Table 1 summarises the distinguishing features of these approaches and illustrates how they are reflective of different policy objectives regarding the broader effect of systemic risk on financial stability.

There are several methodological proposals that coexist in a loose manner. The growing literature on systemic risk measurement is the result of greater demand placed on the ability to develop a better understanding of the interlinkages between firms and system-wide vulnerabilities to risks as a result of the (assumed) collective behaviour under common distress. Most of the prominent institution-level measurement approaches, such as CoVaR, ${ }^{10,11}$ CoRisk, ${ }^{12}$ Systemic Expected Shortfall (SES), ${ }^{13,14}$ Granger Causality, ${ }^{15}$ SRISK $^{16}$ and Systemic Contingent Claims Analysis, ${ }^{17}$ have focused on the "contribution approach" by including an implicit or explicit treatment of statistical dependence in determining the role of SIFIs in causing material distress within a defined system. ${ }^{18}$

The distinction of measurement approaches also reflects varying channels of risk transmission, with banks and non-bank financial institutions causing systemic risk differently. Although banks are prone to contribute to systemic risk from individual failures that propagate material financial distress or activities via intra-and inter-sectoral linkages to other institutions and markets (based on direct exposures via lending and investment) and threaten to cause disruptions to the functioning of the financial sector infrastructure due to a lack of substitutability ("contribution approach"), non-bank financial institutions tend to be more affected by their common exposures to asset price shocks that challenge the overall resilience of the sector ("participation approach").

\section{Systemic risk measurement for the insurance sector}

Although several of these core principles determining systemic relevance apply universally, any assessment methodology would need to be flexible enough to take into account of the fact that the various types of financial institutions perform different functions within the financial system. Understanding the differences in business models, behavioural characteristics under stress, and their structural implications for the financial sector are fundamental to the qualified assessment of their influence on potential transmission channels (as mentioned above) and, by extension, affect the real economy. However, they should not inhibit approaches aimed at comprehensively measuring systemic relevance, covering all types of

${ }^{10}$ Adrian and Brunnermeier (2008).

${ }^{11}$ Note that this term represents a conditional probability measure based on a threshold defined by the "value-atrisk" (VaR).

12 Chan-Lau (2010).

13 Acharya et al. (2009, 2010, 2012).

14 As well as extensions thereof, such as the distress insurance premium (DIP) by Huang et al. (2009, 2010).

15 Billio et al. (2010).

${ }^{16}$ Brownlees and Engle (2011).

${ }^{17}$ Gray and Jobst (2010, 2011a, b); Jobst and Gray (2013).

${ }^{18}$ For a more comprehensive summary of important systemic risk models, see Jobst (2013). 
Table 1 General systemic risk measurement approaches

\begin{tabular}{|c|c|c|c|}
\hline & $\begin{array}{l}\text { Contribution approach } \\
\text { ("Risk agitation") }\end{array}$ & $\begin{array}{l}\text { Participation-contribution approach } \\
\text { ("Risk amplification") }\end{array}$ & $\begin{array}{l}\text { Participation approach } \\
\text { ("Risk absorption") }\end{array}$ \\
\hline Concept & systemic resilience to individual failure & individual susceptibility to amplify a common shock & $\begin{array}{l}\text { individual resilience and capacity } \\
\text { to absorb a common shock }\end{array}$ \\
\hline Description & $\begin{array}{l}\text { contribution to systemic risk conditional on } \\
\text { individual failure due to knock-on effect }\end{array}$ & $\begin{array}{l}\text { contribution to systemic risk due to insufficient resilience to shared } \\
\text { exposure and risk concentration }\end{array}$ & $\begin{array}{l}\text { mitigation of expected loss from } \\
\text { systemic event due to structural } \\
\text { buffers to absorb shocks to shared } \\
\text { exposure and risk concentration }\end{array}$ \\
\hline Risk transmission & "institution-to-institution" & "aggregate-to-institution-to-aggregate" & "aggregate-to-institution" \\
\hline \multirow[t]{3}{*}{ Risk scope } & probability of systemic risk & \multicolumn{2}{|l|}{ scale of systemic risk } \\
\hline & $\begin{array}{l}\text { economic significance of intra-financial } \\
\text { asset holdings and liabilities ("size") }\end{array}$ & claims on other financial sector participants & $\begin{array}{l}\text { obligations on other financial } \\
\text { sector participants }\end{array}$ \\
\hline & $\begin{array}{l}\text { intra- and inter-system liabilities } \\
\text { ("connectedness") }\end{array}$ & \multicolumn{2}{|c|}{ market risk exposure (interest rates, credit spreads, currencies) } \\
\hline \multirow[t]{2}{*}{ Risk indicators } & $\begin{array}{l}\text { degree of transparency and resolvability } \\
\text { ("complexity") }\end{array}$ & \multicolumn{2}{|c|}{ risk-bearing capacity (solvency and liquidity buffers, leverage, time horizon) } \\
\hline & $\begin{array}{l}\text { participation in system-critical function/ } \\
\text { service, for example, payment and settlement } \\
\text { system ("substitutability") }\end{array}$ & \multicolumn{2}{|c|}{$\begin{array}{l}\text { economic significance of asset holdings, term structure transformation/maturity } \\
\text { mismatches ("asset liquidation") }\end{array}$} \\
\hline \multirow[t]{2}{*}{ Policy objectives } & $\begin{array}{l}\text { avoid/mitigate contagion effect (by } \\
\text { containing systemic impact upon failure) }\end{array}$ & \multicolumn{2}{|c|}{$\begin{array}{l}\text { maintain overall functioning of system and maximise survivorship of sound institutions } \\
\text { (with endogenous shock absorbers) }\end{array}$} \\
\hline & avoid moral hazard & preserve mechanisms of collective burden sharing & $\begin{array}{l}\text { encourage diversity of business } \\
\text { models and risk management }\end{array}$ \\
\hline
\end{tabular}

Note: The policy objectives and indicators to measure systemic risk under both contribution and participation approaches are not exclusive to each concept. Moreover, the availability of certain types of balance sheet information and/or market data underpinning the various risk indicators varies between different groups of financial institutions, which requires a certain degree of customisation of the measurement approach to the distinct characteristics of a particular group of financial institutions, such as insurance companies.

Sources: Drehmann and Tarashev (2011), FSB (2011a), Weistroffer (2011), and Jobst and Gray (2013). 
financial institutions, to the extent that the timely identification of a build-up of systemic risk might be compromised.

The different nature of risk taking of banks and insurance companies suggests limited usefulness of existing methods to identify systemic risk. Established (bank-focused) approaches to systemic risk are instructive but require careful assessment as to their adaptability for the design of an effective framework for the insurance sector. ${ }^{19}$ Although insurance companies share some similarities with banks, such as the management of cash flows over different risk horizons to satisfy payment claims arising from providing financial services, their leverage does not result from liquidity or maturity transformation and is hardly susceptible to the cyclicality of funding sources. Banks leverage their asset base by incurring short-term liabilities (deposits and/or debt securities) to fund their lending and investment business. ${ }^{20}$ In contrast, the leverage of insurance companies is client-driven, since it reflects the desired collateralisation of future payment obligations (via technical provisions) and, thus, is endogenous to the underwriting performance (rather than a strategic business decision regarding risk appetite in financial intermediation). ${ }^{21}$

Most supervisory concerns about insurance activities tend to arise from liquidity rather than solvency risk; however, insurers aim to closely match the duration of assets and liabilities. Insurance companies pursue a predominantly liability-driven investment approach to ensure that they can meet their policyholder obligations arising from such underwriting risk (especially for non-life insurance firms), which is largely idiosyncratic and generally independent of the economic cycle. Cash inflows from unearned premiums are invested such that payments of future (unsure) claims can be made at all times, which explains why assetliability matching plays such a critical part of an insurer's profitability, especially during adverse economic conditions that might negatively affect investments over prolonged periods of time. Claims can normally be paid via the sale of liquid assets that generate commensurate cash inflows (as opposed to traditional financial intermediation, which involves maturity transformation). The pre-paid funding model (with the possibility of continued collection of premiums even in a recovery or resolution phase), the longer duration of the claims process and penalties for early surrenders of life insurance policies make insurers generally less susceptible to liquidity runs and spillover effects from interlinkages during times of systemic stress. Thus, insurers can be insolvent (or insufficiently solvent) and still remain liquid due to the long-term nature of the business model.

Therefore, institutional failures of insurers have arguably a different impact on the financial system than those in the banking sector, and the way in which they might create and/or propagate systemic risk due to key differences between banks and insurance companies: ${ }^{22}$

- Risk types and links to the economy. Insurance companies are exposed to risks commonly found in other financial institutions, including credit risk, operational risk and market risks

\footnotetext{
19 BCBS (2012).

${ }^{20}$ However, given the scarcity of sufficiently long-term assets, insurers often tend to have a negative duration gap ("short-long mismatch") whereas the opposite applies to banking ("long-short mismatch").

${ }^{21}$ Moreover, insurance leverage trends to increase after a large claim due to higher technical provisions and lower equity (which contrasts with rising leverage as a sign of risk build-up in the banking sector).

${ }^{22}$ See Geneva Association (2010a, b, 2011a, b, c, 2012a) and IAIS (2010b, 2011a, 2012b) for a thorough review of the possible systemic relevance of insurance activities.
} 
related to equity investments as well as adverse movements in interest rates and exchange rates, all of which are highly correlated with changes in economic conditions; however, risks from underwriting (e.g. mortality, morbidity, property and liability risks) are generally independent of the economic cycle, which allows them to realise additional diversification gains (through investment in inversely related assets, risk pooling or risk sharing via reinsurance), whereas banks, by the acceptance of deposits and granting of loans, might find it more difficult to reduce their credit risk (from lending) or liquidity risk (from the maturity mismatch in borrowing short and lending long).

- Integration in financial sector infrastructure. As insurance firms are not part of payments or clearing systems essential to economic activity (which they access but do not have responsibility for organising), they tend to hold only limited direct intra-system claims and liabilities and exhibit relatively low levels of interconnectedness with the rest of the financial system both domestically and across national boundaries. Even though large insurance groups have a global presence, they also do not provide essential financial market utilities and are generally less integrated in the financial sector infrastructure than banks. Thus, individual failure does not have the same negative systemic impact as the failure of a bank would. In fact, failures take place over an extended time period that allows for orderly planning as part of stable processes that do not lead to destabilising runs. Also, many less complex insurance products limit systemic risk from the uniqueness of insurance capacity offered by a failing institution. However, the interlinkages between insurers, banks and other financial institutions may increase in the future through products, markets and conglomerates, which warrants enhancements to supervisory processes, combined with stronger risk management and flexible approaches to resolvability in order to minimise adverse externalities.

- Risk transfer and absorption. The risk-absorbing capacity of insurance firms-together with their different business characteristics from banks-is likely to reduce systemic risk in general (see Table 1). As opposed to risk transfer of bank assets, insurance risks are kept in general on the balance sheet, which mitigates the risk of moral hazard generated by the separation of origination and distribution activities through securitisation. Two types of risk transfer activities are most important in this regard-reinsurance and derivatives transactions. Although the trading of derivatives for hedging purposes and the underwriting of reinsurance contracts are generally considered traditional functions, all nonhedging/non hedge replicating derivatives and the issuance of CDS protection are deemed non-insurance activities in the absence of insurable interest. ${ }^{23,24}$ The reinsurance of primary underwriters and the acceptance of ceded insurance risk between reinsurers (i.e. retrocession) involve only a partial transfer of risk, with most risk staying on the ceding (re)insurer's balance sheet. Since reinsurance improves the diversification of risks over different business lines and across national boundaries, it also facilitates the optimal allocation of capital.

- Funding structure. In the absence of maturity transformation, consumer or commercial credit, or transaction clearing services, insurers exhibit a liquidity position that is less

23 IAIS (2012b).

${ }^{24}$ The IAIS (2011a) defines insurable interest as "an interest in a person or a good that will support the issuance of an insurance policy; an interest in the survival of the insured or in the preservation of the good that is insured. [...] Financial derivatives are not considered insurance for regulatory purposes". 
influenced by external funding conditions due to strong operating cash flows via upfront premium payments together with a longer-term investment horizon compared with other types of financial institutions. Insurance operations are deemed to be stabilisers to the financial system through a so-called "inverted production cycle", that is, firms are funded by reserves (through upfront premium payments), resulting in stable cash flows to the insurer (unlike in the banking model). Even though insurers are only partially selffunded (as the bulk of their funding stems from reserves), reserves are usually longer term than common funding sources (interbank or wholesale market liabilities) of commercial banks.

- Characteristic of cash outflows. Also most cash outflows of insurance companies are determined by the timing and administration of policyholder claims (rather than debt payments to creditors). The payment of insurance claims differs significantly from the execution of margin calls and/or the satisfaction of depositor claims in the banking sector. Insurers are not predisposed to sudden cash withdrawals, as most insurance liabilities are not redeemable on demand by policyholders (like bank deposits) and require a triggering event, whose probability is independent of general economic conditions. Even though some forms of life insurance may be viewed as savings products, most contracts have tax and contractual disincentives for policyholders to surrender the insurance policies before its contractual maturity (i.e. insurance reserves are not instantaneously "puttable" like deposits). Conversely, where reserves are "puttable", the policyholder bears the investment risk (unit-linked, separate accounts).

Thus, the distinct characteristics of the insurance business model suggest a lower susceptibility to cause (or amplify) systemic risk. Insurance companies pursuing traditional underwriting activities (defined by insurable interest subject to insurance accounting and regulations) are generally considered to represent a lower level of systemic risk than banks, mainly because of the different character of their liabilities and the lower degree of interconnectedness to other financial institutions and capital markets.

However, non-core underwriting and investment activities-with no direct connection to the traditional business model-might be subject to systemic risk considerations. Most of these systemically relevant activities tend to amplify rather than induce systemic risk (in keeping with the "participation approach" (see Table 1)) and typically arise on the group level in the context of changing business models. For instance, insurance companies have extended their underwriting activities to non-traditional features, such as different types of financial lines (including mortgage guarantee, financial guarantee, fidelity and surety) and reinsurance contracts with modified risk transfer, which can materially affect the risk profile of contracts. Moreover, traditional funding activities have become mixed with nontraditional activities, such as extensive securities lending and liquidity swaps. These noncore activities (rather than specific institutional arrangements) as sources of systemic risk require a nuanced consideration of the relative importance of the various channels of systemic risk transmission, such as connectedness, substitutability and the timing of payment/asset liquidation, with a greater emphasis on systemic risk participation, with large shocks to common exposures affecting the overall functioning of the sector.

Although traditional insurance activities have not contributed to systemic risk during the financial crisis, the interlinkages between insurers on the one hand and financial markets, banks, other insurance companies as well as the real sector (non-financial corporations and 


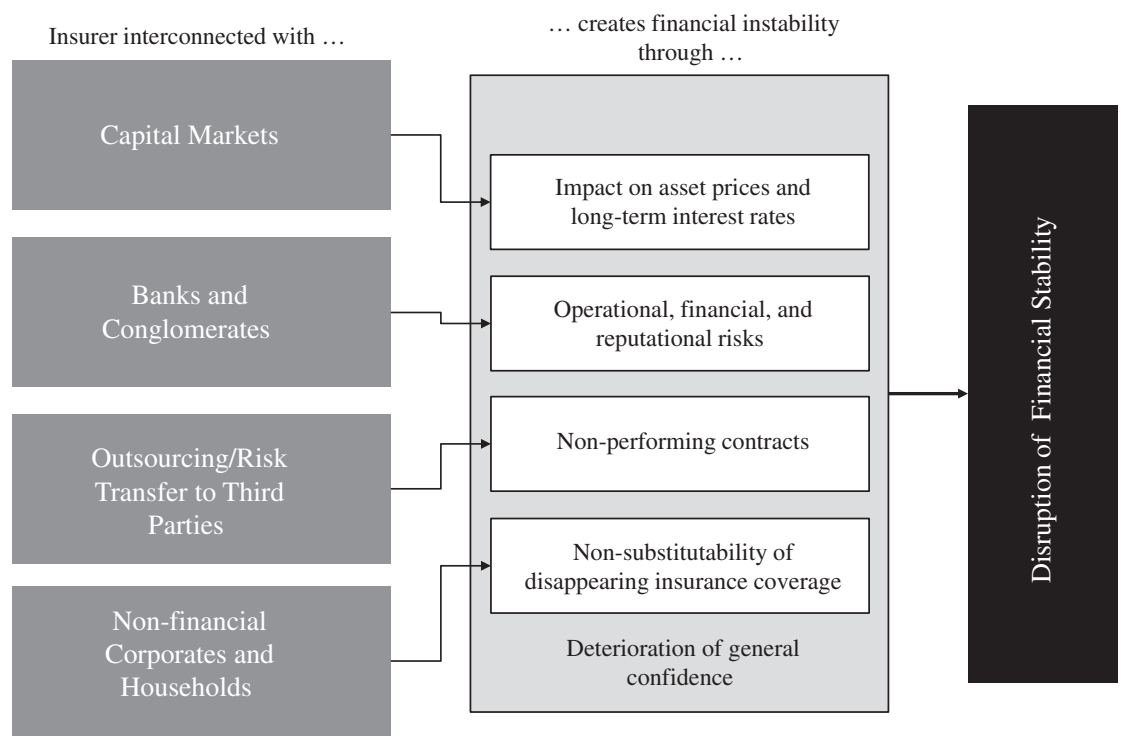

Figure 1. Macro-financial linkages of insurance activities.

households) on the other ${ }^{25}$ (Figure 1) may increase in the future through products, markets and conglomerates. While the long-term nature of many insurance business models with a low "puttability" of reserves implies a high capacity to absorb shocks, it also puts a premium on the reliability of actuarial methods, especially during times of stress when valuation models might fail to fully reflect potential downside risks and distort the true value of both assets and liabilities.

There are also potential sources of systemic risk associated with long-term trends that could negatively affect the insurance sector, such as climate change, the secular decline of real interest rates and longevity. Even though these risks impact primarily the solvency condition of firms (which is less relevant for systemic risk concerns arising from illiquidity), if not addressed and mitigated in time (especially in areas of homogenous firm behaviour), could potentially compromise the long-term viability of certain lines of business.

\section{Identifying systemically relevant insurance activities and systemically important insurance companies}

\section{Initial regulatory proposals and industry suggestions}

At the end of 2009, the Financial Stability Committee (FSC) of the IAIS ${ }^{26}$ started first consultations with the insurance industry towards establishing a globally binding assessment framework for systemically important insurance companies. At the time, the development of

\footnotetext{
${ }^{25}$ Houben and Teunissen (2011).

${ }^{26}$ IAIS (2009).
} 
systemic risk measurement in general, and for the insurance sector in particular, was still in its infancy. Given the limited experience in insurance-specific macroprudential surveillance activities in relation to systemic risk at both domestic and global levels, ${ }^{27}$ the IAIS initially followed the rationale of identifying SIFIs in the banking sector, which defines several quantitative indicators of systemically relevant activities. These systemic risk indicators-cross-jurisdictional activity, size, interconnectedness, substitutability and timing-would all need to be triggered for a determination of systemic risk relevanceafter considering the impact of all aggravating and mitigating factors, such as internal risk controls, posted collateral and the scope of supervisory oversight on the assessment of systemic relevance.

In addition, the IAIS $^{28}$ viewed the complexity of insurance companies (and their transactions) as an important criterion in the determination of systemic risk, which involves their resolvability as a qualitative determinant of systemic relevance. Thus, the likelihood of an insurance company to be resolved or restructured in an orderly procedure if it were to fail without causing a systemic event was taken as an additional consideration with regard to operational and legal complexity giving rise to systemic importance. ${ }^{29}$

In response to the early efforts of the IAIS of relating systemic importance to institutional characteristics, The Geneva Association ${ }^{30}$ proposed a shift of focus away from the risk indicator-based approach towards particular activities that could cause systemic risk in the insurance sector and the financial system at large. It suggested an activity-based approach of identifying potentially systemically risky activities (pSRA), with a particular focus on derivatives trading and short-term liquidity risk management.

\section{Discussion of industry-suggested systemic risk indicators}

In 2011, the insurance industry proposed the adoption of several broad risk indicators for the evaluation of non-core insurance activities-financial guarantees, derivatives underwriting - and short-term liquidity mismanagement as sources of systemic relevance. In furtherance of the activity-based approach of identifying potentially pSRA, The Geneva Association ${ }^{30,31}$ suggested several indicator-based metrics that combined these insurance activities with the different channels of risk transmission-size, interconnectedness, substitutability and timing (see Table 2), which were identified in earlier attempts at specifying systemically important insurance companies consistent with the general principles established by the IAIS. ${ }^{28}$ Although the proposed risk indicators avoid complex valuation models, they are based on static and microprudential measures, and, thus, assess the cross-sectional dimension of systemic risk only from a supervisory perspective without considering the market dynamics of derivatives trading and liquidity management. For instance, short-term funding activities would be most suitably addressed by liquidity risk indicators that can qualify the

\footnotetext{
27 IAIS (2010a).

${ }^{28}$ IAIS (2011a).

${ }^{29}$ However, established resolution regimes for insurers can be effective in limiting the impact of individual failure on policyholders (and ultimately its implications for fiscal policy).

30 The Geneva Association (2011a, b).

${ }^{31}$ See also Liedtke (2011).
} 
Table 2 Quantitative indicators of systemically important activity in the insurance sector-Current industry proposal (Geneva Association) and adaptation to the supervisory framework in Bermuda

$\begin{array}{cc}\text { Geneva Association (2011) Suggested approach } & \text { Derivatives activities }\end{array}$

Derivatives activities

Description

Adverse result

Size $e^{\mathrm{a}}$

Connectedness

Substitutability

Timing

Description

Adverse result

Size $e^{\mathrm{b}, \mathrm{c}}$

Derivatives underwriting and trading without genuine hedging interest: risk-taking activities with non-insurance legal entities for speculative purposes, with positions neither entering the economic capital assessment nor supervisory oversight; this contrasts with derivative activities to hedge market risk.

Margin calls to multiple entities could exceed available financial resources and cause higher susceptibility to common asset price shocks $\rightarrow$ expected participation of entity in systemic risk event and losses to creditors ("participation in systemic risk").

Market value of net written (OTC) derivatives (offset for collateral and direct counterparty trades) plus add-on for stress market environment

Market value of net written (OTC) derivatives (offset for collateral and direct counterparty trades) to financial institutions

Shareholders' equity of financial institutions

Market value of net written (OTC) derivatives (offset for collateral and direct counterparty trades)

Global (OTC) market value of derivatives (net of posted collateral)

Immediate (criteria triggered)

\section{Short-term funding activities}

Mismanagement of short-term funding as part of regular funding activities by investing in illiquid (short-term) assets through short-term debt or securities lending (possibly combined with excessive risk taking); this contrasts with capital raising and long-term debt funding and securities lending for insurance activities only.

Cash outflows could exceed available financial resources and cause contagion in times of stress $\rightarrow$ marginal distress on the system conditional on the individual entity failing ("contribution to systemic risk").

(1) Market value of potential liquidity needs at the group level if al immediate positions are called and/or

(2) market value of potential liquidity needs at the group level if all immediate positions are called minus immediately available liquid asset
Liquid assets to probable maximum losses (PML) and actual attritional losses (both single entity and group level)

Total liquid assets held by financial institutions (within sector/system) 
Connectedness

Market value of potential liquidity needs at the group level if all immediate positions are called

Total liquid assets held by financial institutions (within sector/

system)

Substitutability
"Market concentration" of liquid assets to PML and actual attritional losses (both single entity and group level) based on concentration index

Concentration of liquid assets to PML and actual attritional losses (both single entity and group level) for entire system

Concentration of liquid assets to PML and actual attritional losses (both single entity and group level) for entire system without firms that have a liquidity shortfall/deemed systemically important

"Excess contribution" of firm's liquid assets to PML and actual

attritional losses (both single entity and group level) to sample variance

of "market concentration"

Positions callable within 12 months

${ }^{a}$ The offsetting effect of collateral is not a straightforward exercise as collateral itself might be subject to asset funding risk in times of stress. For Bermuda insurance firms, the scale of direct counterparty trades could not be ascertained.

${ }^{\mathrm{b}}$ The immediacy of payments refers to short-term financing instruments, derivatives and securities lending.

${ }^{c}$ In both cases, any funding shortfall (i.e. liquidity needs after offsetting effect of asset sales (left side) or liquid assets relative to expected (actuarially-derived) cash outflows from losses) would need to be scaled relative to overall liquidity conditions of the sector-domestically, internationally and/or both

${ }^{\mathrm{d}}$ The concentration of liquidity needs is defined based on the Herfindahl-Hirschman index (HHI): $\sum_{N}(\text { market share of firm })^{\wedge} 2$ (within the range 0 to 1 as a normalised measure) for $N$ number of firms in the sample (Hirschman, 1964); the first "substitutability ratio" in the right column represents the "marginal contribution" to the "market concentration" of liquidity risk.

Note: $\mathrm{PML}=$ probable maximum losses.

Sources: The Geneva Association (2011a, b) and Liedtke (2011). 
connectedness via exposures to particular counterparties (possibly conditional on their creditworthiness).

Adaptation and suggested enhancements of industry-suggested systemic risk indicators for liquidity risk

In this section, we examine whether insurance activities that have generally been considered systemically relevant on a global scale, such as short-term liquidity mismanagement, ${ }^{32}$ also pose similar risks for (re)insurers sector in Bermuda. In particular, we investigate the general usefulness of the liquidity risk indicators according to the activity-based assessment method put forth by The Geneva Association and propose suggestions for their modification and, where appropriate, suitable enhancements consistent with the overall concept of identifying systemically important insurance activities suggested by the IAIS in the course of developing the G-SII assessment methodology. Thus, our analysis also provides valuable insights into the relevance of systemic risk indicators within an insurance market that is largely focused on non-life underwriting activities outside the home jurisdiction.

\section{Discussion of liquidity risk indicator}

The transmission channels of relative size, connectedness and substitutability serve as a starting point for analysing short-term funding risks from illiquid asset holdings as a frequently mentioned source of systemic risk ${ }^{33}$ as the basis for an empirical application using prudential data of the Bermuda insurance sector.

- Size: We define the size indicator of liquidity risk as liquid assets to probable maximum losses (PML) and actual attritional losses (or alternatively, only net PML or net losses and loss expense provisions as scaling factors). This potential funding shortfall of liquid assets relative to expected (actuarially-derived) cash outflows from loss claims would need to be scaled relative to a firm-specific measure of liquidity and/or solvency, such as total liabilities (which generates the liquidity ratio). In addition, the cross-sectional variation of this indicator would also require qualifying the identified liquidity shortfall based on the economic significance of liquid assets of the firm relative to the maximum potential liquidity in the system, that is, the total liquid assets reported by all sample firms,

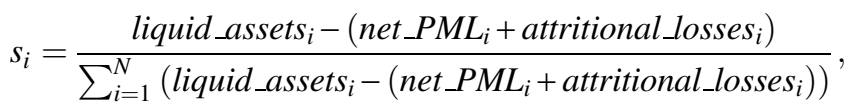

for a pre-specified threshold.

- Connectedness: In the absence of firm-by-firm data on lending and borrowing relationships within and across the sector, the distribution of short-term funding risk (and the degree to which interlinkages between firms could cause systemic risk from liquidity shortfall) can be approximated using the concentration of liquid assets to different scaling factors (such as net PML and actual attritional losses), possibly in combination with the

\footnotetext{
32 The Geneva Association (2011a); IAIS (2011c).

${ }^{33}$ IAIS (2011a); Liedtke (2011).
} 
concentration of funding sources of individual entities. The concentration measure is defined based on the normalised Herfindahl-Hirschman index (HHI) in percentage terms, $^{34}$

$$
H H I_{N}^{*}=\frac{\sum_{i=1}^{N} \widehat{s}_{i}^{2}-\frac{1}{N}}{1-\frac{1}{N}} \times 100=\frac{H H I_{N}-\frac{1}{N}}{1-\frac{1}{N}} \times 100 \in[0,100],
$$

where

$$
\begin{aligned}
& \left(\text { liquid_assets }_{i}-\left(\text { net_PML } L_{i}+\text { attritional_losses }_{i}\right)\right)
\end{aligned}
$$

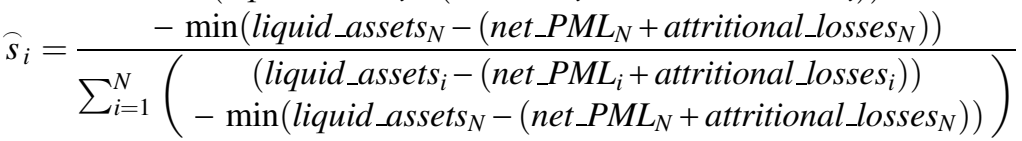

which represents the "market share" of liquidity surplus/shortfall for $N$ number of firms, measured as the ratio between the difference of liquid asset and PML and actual attritional losses of firm $i$ (numerator), and the sum of liquidity surplus/shortfall for all firms in the sample (i.e. all Class 4 or Class 3B insurance companies). The specification of $\widehat{s}_{i}$ in Eq. (3) above reflects a shifted distribution of liquidity surplus/shortfalls to generate positive values only.

- Substitutability: We measure the degree of substitutability as the contribution of individual liquidity needs to the concentration of overall liquidity risk by calculating the degree to which each firm $j$ with liquidity shortfall (measured as the difference of liquid asset and PML and actual attritional losses) contributes to the asymmetry of the concentration measure $H H I_{N}^{*}$ of overall liquidity risk (see Eq. (2) above). More specifically, the "excess contribution" of each firm is measured either as its share of the total statistical variance,

$$
\Delta V_{j, N, 1}=\frac{\left(\widehat{s}_{j}-\frac{1}{N}\right)^{2}}{\sum_{i=1}^{N}\left(\widehat{s}_{i}-\frac{1}{N}\right)^{2}} \times 100,
$$

or its contribution relative to the average contribution of each firm,

$$
\Delta V_{j, N, 2}=\frac{N\left(\widehat{s}_{j}-\frac{1}{N}\right)^{2}}{\sum_{i=1}^{N}\left(\widehat{s}_{i}-\frac{1}{N}\right)^{2}} \times 100,
$$

which should be $1 / N$ and zero, respectively, if the liquidity surpluses/shortfalls were homogenously distributed (i.e. all firms have-on average-equal (identical) liquidity surpluses/shortfalls) and, thus, liquidity risk is completely symmetric, so that $\widehat{s}_{i}=1 / N$ for firm $i$ and

$$
H H I_{N}^{*}=\frac{1}{N}+N V_{N} \stackrel{V_{N}=0}{\longrightarrow} \frac{1}{N}
$$

\footnotetext{
${ }^{34}$ The asterix indicates the HHI in its normalised form.
} 
where $V_{N}$ is the statistical variance ${ }^{35}$

$$
V_{N}=\frac{1}{N} \sum_{i=1}^{N}\left(\widehat{s}_{i}-\frac{1}{N}\right)^{2}=0 .
$$

Alternatively, we define the "marginal contribution" of this firm to the normalised HHI measure (see Eq. (1) above) as

$$
\Delta H H I^{*}=\left(\frac{H H I_{N}^{*}}{H H I_{N-1}^{*}}-1\right) \times 100=\left(\frac{\left(\sum_{i=1}^{N} \widehat{s}_{i}^{2}-\frac{1}{N}\right)\left(1-\frac{1}{N-1}\right)}{\left(\sum_{i=1}^{N-1} \widehat{s}_{i}^{2}-\frac{1}{N-1}\right)\left(1-\frac{1}{N}\right)}-1\right) \times 100,
$$

where $j \notin N$.

All risk indicators would ideally be extended to fully capture the different types of risk transmission and their impact on financial stability both within a particular country and across national boundaries ("cross-sectional dimension"). Individual risk indicators could be modified to reflect the total effect of any firm (beyond the magnitude of liquidity shortfall as the distinguishing feature) and/or the joint effect of multiple firms on system-wide liquidity risk (and extent to which short-term funding activities pose systemic risk). ${ }^{36}$

Also the variability of system-wide vulnerabilities to common adverse shocks needs to be addressed ("time-varying dimension"). In the case of liquidity risk from short-term funding activities, a simple or weighted average over a pre-defined risk horizon could be calculated as a "through-the-cycle" measure, subject to the frequency of statutory reporting. ${ }^{37}$

\section{Empirical findings for large commercial (re)insurers (Class 4 and 3B) in Bermuda}

We obtained prudential information from the annual Bermuda Solvency Capital Requirement (BSCR) filings of 45 registered Class 4 and 3B commercial (re)insurers. The BSCR represents a principles-based regulatory regime that is geared towards understanding the risk profile or characteristics of Bermuda (re)insurers consistent with similar approaches in other jurisdictions. It was established under the Insurance (Prudential Standards) (Class 4 and 3B Solvency Requirement) Rules 2008 (the "Rules") by the Bermuda Monetary Authority (BMA) in combination with the Guidance Note No. 17 on Commercial Insurer Risk Assessment. Together with the Insurance Act 1978, Insurance Returns and Solvency Regulations 1980, Insurance Accounts Regulations 1980 (which were amended in 2008) and the Insurance Code of Conduct 2010, it forms the regulatory regime for the (re)insurance sector in Bermuda. ${ }^{38}$

\footnotetext{
${ }^{35}$ If the number of firms in the market is held constant, then a higher variance due to greater asymmetry of liquidity risk would result in a higher index value (Brown and Warren-Boulton, 1988).

${ }^{36}$ In the case of liquidity risk, Eqs. (3) and (6) could be extended to multiple firms, for instance.

37 BCBS (2009).

${ }^{38}$ The insurance classification scheme categorises large commercial insurance companies into three main groups -Class 4, Class 3B and 3A insurers (BMA, 2008; 2012a,b). The Class 4 insurance category comprises (re)insurers capitalised at a minimum of US $\$ 100$ million underwriting direct excess liability and/or property catastrophe reinsurance risk. Class 3B firms are large commercial insurers whose percentage of unrelated business represents 50 per cent or more of net premiums written or loss and loss expense provisions (and/or where the unrelated business net premiums are more than US\$50 million). Since only Class 4 and 3B insurance companies were subject to the standardised solvency assessment under the BSCR framework until end-2010, the empirical analysis excludes Class $3 \mathrm{~A}$ insurers, and, thus, covers only large commercial (re)insurers.
} 
Table 3 Bermuda Class 4 and 3B (re)insurance Firms_-Liquidity conditions, 2007-2011

\begin{tabular}{|c|c|c|c|c|c|c|c|c|}
\hline \multirow{3}{*}{ Liquidity indicators (in per cent) } & \multirow[b]{3}{*}{ Year } & \multicolumn{7}{|c|}{ Insurance classes } \\
\hline & & \multicolumn{5}{|c|}{ Class 4 only } & \multicolumn{2}{|c|}{ Class 4 and $3 B$} \\
\hline & & 2007 & 2008 & 2009 & 2010 & 2011 & 2010 & 2011 \\
\hline Liquid assets to total liabilities & & 262 & 270 & 197 & 185 & 143 & 201 & 141 \\
\hline Liquid assets to net PML & & 1,048 & 1,009 & 861 & 924 & 743 & 1,033 & 934 \\
\hline Liquid assets to net PML and actual attritional losses & & 396 & 374 & 312 & 327 & 314 & 250 & 311 \\
\hline Liquid assets to net loss expense provision & & 624 & 507 & 338 & 287 & 216 & 513 & 421 \\
\hline Number of firms & & 30 & 30 & 30 & 30 & 33 & 45 & 49 \\
\hline
\end{tabular}

Note: $\mathrm{ECR}=$ enhanced capital requirement, $\mathrm{PML}=$ probable maximum losses. In calculating the liquidity ratios above, the following assets are considered to be liquid assets: cash and time deposits, total quoted investments, total unquoted investments, investment income due and accrued, total accounts and premiums receivable, and reinsurance balances receivable. Non-investment grade and unrated fixed income securities are excluded from total investments for this calculation.

Source: Bermuda Monetary Authority (BMA).

Over the sample period between 2007 and 2011, we found that large commercial (re) insurance companies do not seem vulnerable to short-term liquidity risk, which has been deemed systemically important in current policy proposals. More specifically, our findings suggest that:

- Despite a record level of insured losses in 2011, liquidity positions of firms remained broadly resilient. Even though liquidity levels have remained stable for most of the sample period, above-average claims activity during 2011 resulted in a significant decline, albeit from a very high starting level. Since our sample comprises (re)insurance companies with largely short-tailed property and casualty $(\mathrm{P} \& \mathrm{C})$ exposure, however, there are no callable short-term liabilities from surrenders by policy holders (but rather external events). Thus, liquidity risk would arise primarily from asset-liability mismatches (and short-term liquidity mismanagement).

- Firms held high liquidity buffers well above prudential requirements to ensure a high claims paying ability relative to net probable maximum losses (PML) and attritional losses (i.e. losses other than those related to major catastrophes or exposures, which can impact reserves up to seven or eight years (sometimes more) after a loss event) as a measure of worst-case short-term cash flow demands. ${ }^{39}$ As a general indicator of liquidity (and the relative size of outstanding contracts), the ratio of liquid assets to net PML declined only by 8.4 per cent during the financial crisis between 2007 and 2010, and stood at 743 per cent at end-2011 (see Table 3). However, a considerable decline of liquid assets relative to changes in net loss and loss expense provisions highlights that low premium levels over the last three years and record losses in 2011 have not only put greater focus on reserve adequacy but also adversely affected system-wide liquidity.

\footnotetext{
${ }^{39}$ Although the BMA uses this measure for conservatism on account of uncertainty of contents, attritional losses arising from catastrophe exposure contracts may already be reflected in the net PML.
} 
- Insurers with potential liquidity shortfall under stress did not seem to have systemic relevance. Although four insurers did not meet the liquidity ratio and show a disproportionate contribution to system-wide liquidity risk at end-2011, their economic significance was very small, with results indicating a low probability of material financial distress within the sector caused by an adverse short-term funding scenario (see Table 4$){ }^{40}$ More specifically, at end-2011, we find that these firms represent barely more than 2.4 per cent of aggregate liquid assets in the sample, but increase the concentration of liquidity risk by more than 31 per cent.

However, further analysis of institutional linkages and concentration of both investments and liabilities is needed for a more comprehensive assessment of spillover effects from liquidity risk, which can help inform the forward-looking assessment of system-wide vulnerabilities. ${ }^{41}$

\section{Current assessment methodology for systemically important insurance companies (G-SIIs)}

Policy discussions and industry consultations helped narrow the supervisory perspective on the systemic relevance of insurance activities in the process of developing a viable assessment methodology. The IAIS converged to the industry view that traditional insurance business - with the exception of general vulnerabilities to common asset price, disruptions to market functioning and cyclical pressures-is unlikely to generate and/or amplify systemic risk within the financial system (and the real economy). ${ }^{42}$ Since most insurance techniques rest on the pooling of a large number of ideally uncorrelated risks, ${ }^{43}$ an increase of a well-diversified underwriting portfolio lowers unexpected losses as the probability of very large losses (relative to the size of the portfolio) decreases. As a result, the IAIS clarified its original conceptual approach to systemic risk by acknowledging that primarily certain (non-core) activities - if conducted on a large scale without adequate prudential oversight—rather than institutional fragility per se could pose system-wide vulnerabilities. $^{27}$

On 18 July 2013, the IAIS $^{44}$ published its final version of the initial assessment methodology, which comprises five categories of risk drivers that reflect the relative

\footnotetext{
40 The liquidity ratio is calculated using total liquid assets to total liabilities. At end-2011, four companies scored below the 100 per cent threshold, which indicates some potential liquidity need if an insurer would have to immediately settle all callable insurance obligations. However, these results might overstate the actual funding shortfall over a short-term horizon due to limited information on the exact contractual maturity of potential cash outflows for positions callable within three months - the commonly assumed time period for net cash flow stress tests.

${ }^{41}$ Bermuda was not identified as a jurisdiction with a systemically important financial sector for purposes of the IMF's determination of a mandatory completion of the Financial Sector Assessment Program (FSAP) every five years (IMF, 2010). Moreover, as part of an initiative to encourage the adherence by all countries and jurisdictions to regulatory and supervisory standards on international cooperation and information exchange, the FSB (2011b) designated Bermuda as a jurisdiction "demonstrating sufficiently strong adherence".

42 IAIS (2013b).

${ }^{43}$ Liedtke (2011); Lehmann and Lehrer (2011); IAIS (2013b).

${ }^{44}$ IAIS (2013a).
} 
Table 4 Bermuda class 4 and 3B (re)insurance firms—-Level and concentration of liquidity risk, 2007-2011

\begin{tabular}{|c|c|c|c|c|c|c|c|c|c|c|c|}
\hline \multirow[t]{3}{*}{ Concentration of liquidity surplus/deficit } & \multirow[b]{3}{*}{ Year } & \multicolumn{10}{|c|}{ Insurance classes } \\
\hline & & \multicolumn{6}{|c|}{ Class 4} & \multicolumn{4}{|c|}{ Class $3 B$} \\
\hline & & 2007 & 2008 & 2009 & 2010 & 2011 & coeff. of variance & 2009 & 2010 & 2011 & coeff. of variance \\
\hline \multicolumn{12}{|l|}{ All firms } \\
\hline \multicolumn{12}{|l|}{ Concentration measure-Herfindahl-Hirschman index (HHI) } \\
\hline absolute & & 6.10 & 6.77 & 7.27 & 6.21 & 4.81 & 14.82 & 13.46 & 15.49 & 16.92 & 11.36 \\
\hline normalised & & 2.86 & 3.56 & 4.07 & 2.97 & 1.83 & 27.44 & 7.28 & 9.45 & 11.38 & 21.89 \\
\hline variance & & 0.09 & 0.11 & 0.13 & 0.10 & 0.05 & 29.71 & 0.45 & 0.59 & 0.67 & 18.99 \\
\hline \multicolumn{12}{|l|}{ Firms with liquidity shortfall } \\
\hline \multicolumn{12}{|l|}{ Systemic risk contribution to concentration (in per cent) } \\
\hline \multicolumn{12}{|l|}{ Excess contribution to $\mathrm{HHI}$} \\
\hline relative to total variance & & - & 3.23 & - & 6.33 & 13.84 & & 6.54 & - & - & \\
\hline relative to average indiv. contribution to total variance & & - & 96.94 & - & 94.96 & 114.15 & & 98.10 & - & - & \\
\hline Marginal contribution to $\mathrm{HHI}$ & & - & 3.34 & - & 8.95 & 31.90 & & 6.99 & - & - & \\
\hline Share of total liquid assets (In per cent) & & - & 0.99 & - & 1.13 & 2.44 & & 0.03 & - & - & \\
\hline Number of firms & & 0 & 1 & 0 & 2 & 4 & & 1 & 0 & 0 & \\
\hline
\end{tabular}

Note: "coeff. of variance"=standard deviation/average of annual observations over the given time period; the HHI concentration measure, the excess contribution to HHI and the marginal contribution to HHI are defined according to the specifications in Eqs. (2), (4) and (8), respectively.

Source: Bermuda Monetary Authority (BMA). 
458

importance of each indicator for the assessment of systemic relevance of insurers (size, interconnectedness, substitutability, NTNI activities and global activity). Within these five categories are a total of 20 indicators, including intra-financial assets and liabilities, gross notional amount of derivatives, Level 3 assets, non-policyholder liabilities and non-insurance revenues, derivatives trading, short-term funding, liability liquidity, and variable insurance products with minimum guarantees. ${ }^{45}$ The IAIS has assigned weightings as follows: 45 per cent to NTNI activities, 40 per cent to interconnectedness, 5 per cent to substitutability; 5 per cent to size and 5 per cent to global activity. Within all five categories, equal weight is given to each indicator. Each insurer receives one score for each of the indicators, which are then weighted and summed up to form the overall individual score. ${ }^{46,47}$

In its assessment methodology the IAIS acknowledges that the systemic relevance of insurance companies is generally different (and possibly smaller) than that of banks, but maintains the view that the failure of an insurer has the potential to pose risks to financial stability. In particular, interconnectedness and NTNI activities of firms are deemed significant transmission channels for the determination of the systemic relevance of insurers, while size and global activity are deemed less important (relative to other risk indicators within the assessment methodology. Although traditional insurance activities benefit from risk pooling and lower funding risk (as a result of predominantly liability-driven investments, extended pay-out periods for claims, and non-cyclical insurance events), NTNI activities (especially if conducted with multiple counterparties) can be more vulnerable to financial market developments and may therefore be more likely to amplify, or contribute to, systemic risk from general asset price shocks. ${ }^{48}$ Also differences in business models,

${ }^{45}$ Candidate firms for the potential designation as G-SIIs would need to satisfy two eligibility thresholds related to size and global activity. Based on end-2011 values, insurance companies would have to generate 5 per cent or more of gross written premium abroad and report total asset value of US\$60 billion or more at the end of the fiscal year. Alternatively, firms can also be considered based on supervisory judgement.

${ }^{46}$ A set of prudential and market data are used for the calculation of the indicators (e.g. total assets and total revenues are used for the Size indicator).

${ }^{47}$ Paragraphs 35 and 36 of the published assessment methodology describe the procedure used to calculate the score of each indicator as follows: "For each insurer, the score for a particular indicator is calculated by dividing the individual insurer amount by the aggregate amount summed across all insurers in the sample. When an indicator consists of a combination of sub-indicators, the same calculation will be done for each sub-indicator; the results will be averaged to reach the score for the indicator overall. The score is weighted by the indicator weighting within each category. Then, all the weighted scores are added" (IAIS, 2013a, p. 20). For example, a hypothetical simplified Size indicator for a sample of three insurers, "Insurer A" (total assets=US $\$ 300$ ), "Insurer B" (total assets=US\$100) and "Insurer C" (total assets=US\$400), would result in the following individual scores: Insurer $\mathrm{A}=300 / 800=0.375$, Insurer $\mathrm{B}=0.125$ and Insurer $\mathrm{C}=0.5$ so that $\mathrm{A}+\mathrm{B}+\mathrm{C}=1.0$. Subsequently, the individual scores of the 20 indicators are weighted, and then aggregated to obtain an overall score for each insurer. Note that current version the indicator-based assessment approach does not adjust for the differences in individual due to a different number of insurers being engaged in the activities that are measured by a particular indicator. As a result, insurers that are not in a position to engage in such activity (i.e. insurers not licensed or authorised to conduct the activity) are not excluded from the calculation of individual scores, which results in a disproportionately higher score due to sample bias. A possible solution to this problem could be an adjustment procedure. If certain indicators are relevant only for a sample $n<N$ firms of given population $N$ of insurers taking part in the assessment, indicator scores would need to be re-scaled by the factor $1-(N-n) / N$.

${ }^{48}$ Examples of NTNI activities include speculative derivatives trading, guarantees for financial transactions, leveraging assets through securities lending and minimum guarantees on variable insurance products. 
behavioural characteristics under stress and their structural implications for the financial sector influence potential transmission channels for systemic risk. Thus, the IAIS combines the application of the assessment approach with a supervisory judgement and validation process. $^{49}$

In 2013, the FSB ${ }^{50}$ in consultation with the IAIS and national authorities, designated nine insurance groups as G-SIIs, using a revised version of the initial assessment methodology developed by the IAIS. ${ }^{51,52,53}$ The assessment methodology was based on a weighted indicator approach similar to the one developed by the Basel Committee to identify G-SIBs ${ }^{5}$ and reflects the specific nature of the insurance sector, ${ }^{27}$ which has influenced the selection, grouping and weights assigned to certain indicators. Even though the assessment framework also applies to reinsurance companies, the potential G-SII designation of a subset of internationally active reinsurers has been delayed. ${ }^{54}$

Although both G-SII and G-SIB assessment methodologies attribute considerable importance to the interlinkages of firms and the international scope of business activities, there are some salient differences (see Table 5). In contrast to the G-SIB approach, the IAIS' indicator-based assessment methodology for G-SIIs consisting of five categories of risk drivers (i) integrates the "complexity" category (which includes derivatives liabilities and Level 3 assets) into an expanded "interconnectedness" category, (ii) introduces a separate (and heavily weighted) category for NTNI activities (which includes several liquidity risk elements that the G-SIB methodology addressed in its interconnectedness category), and (iii) defines global activities as significant foreign business activities (rather than cross-border claims and liabilities). The methodology is focused on the relative importance of each firm within an indicator-based assessment framework without passing judgement as to the scope and quantum of systemic risk posed by the insurance sector in aggregate (or, collectively by selected sample firms). Like the approach adopted by the Basel Committee, the IAIS does not unify the conjunctural dimensions of systemic risk (as a result of vulnerabilities arising from both cross-

49 This version succeeded "Proposed G-SII Assessment Methodology", which the (IAIS, 2012c) issued for public consultation on 31 May 2012 in the effort to develop and test possible methodologies for identifying G-SIIs (and any coordination that may be required among insurance supervisors). IAIS had previously completed an initial data call of 48 insurance forms in August 2011. The group of G-SIIs will be updated annually and published by the FSB each November based on new data, starting in 2014.

${ }^{50}$ FSB (2013a).

${ }^{51}$ See Annex I; IAIS (2013a).

52 The current list of G-SIIs will be updated annually by the IAIS based on a new data call from candidate firms that meet the minimum criteria of total insurance assets of no less than US\$60 (200) billion and gross written premiums (GWP) of at least (less than) 5 per cent of the group's total GWP are generated outside the home market (or are nominated by their respective supervisory authority). Since the SIFI approaches for G-SIBs and G-SIIs are conditional on a pre-selection of candidate institutions based on a minimum size criterion, they imply different economic significance of a SIFI designation given that G-SIIs are much smaller and less interconnected to other financial services providers than G-SIBs (The Geneva Association, 2012b).

53 The FSB deferred its decision on the G-SII status of, and appropriate risk mitigating measures for, major reinsurers to July 2014.

${ }^{54}$ After preparing the position paper on the role of insurance companies in financial stability analysis (IAIS, 2011a), the IAIS also examined more closely financial stability implications of the reinsurance sector in collaboration with the FSB (IAIS, 2012b). 
Table 5 Selected assessment methodologies for the identification of Systemically Important Financial Institutions (SIFIs)—insurance and banking

\begin{tabular}{|c|c|c|c|c|c|c|}
\hline \multicolumn{2}{|c|}{ FSOC (2011) } & \multicolumn{2}{|c|}{$B C B S(2011)$} & \multicolumn{3}{|c|}{ IAIS (2012c and $2013 b)$} \\
\hline \multirow[b]{2}{*}{ Risk dimension } & \multirow{2}{*}{$\begin{array}{l}\text { Stage } 1-N B F C \\
\text { determination } \\
\text { process }^{\mathrm{a}} \\
\text { Risk factor }\end{array}$} & \multicolumn{2}{|c|}{ G-SIB Methodology } & \multicolumn{3}{|r|}{ G-SII Methodology } \\
\hline & & Risk factor & Weight & Risk factor & Weight & Explanation \\
\hline \multirow[t]{2}{*}{ Size } & \multirow{2}{*}{$\begin{array}{l}\text { Total consolidated } \\
\text { assets }\end{array}$} & \multirow[t]{2}{*}{ Total assets } & \multirow[t]{2}{*}{$20 \%$} & Total assets & $2.5 \%$ & Total balance sheet asset size \\
\hline & & & & Total revenues & $2.5 \%$ & $\begin{array}{l}\text { Sum of insurance gross premium earned, investment income, } \\
\text { realised gains and losses, fees and commissions, other income }\end{array}$ \\
\hline \multirow[t]{6}{*}{ Interconnectedness } & \multirow[t]{2}{*}{$\begin{array}{l}\text { Derivative liabilities } \\
\text { (gross of collateral } \\
\text { and netted for } \\
\text { counterparties) }\end{array}$} & $\begin{array}{l}\text { Intra-financial } \\
\text { liabilities }\end{array}$ & $6.67 \%$ & $\begin{array}{l}\text { Derivative liabilities } \\
\text { Intra-financial liabilities }\end{array}$ & $\begin{array}{l}5.7 \% \\
5.7 \%\end{array}$ & $\begin{array}{l}\text { Gross notional amount of derivatives outstanding } \\
\text { Sum of borrowing from financial institutions and issuance of } \\
\text { securities (debt securities, commercial paper, certificates of } \\
\text { deposit and equity) held by other financial institutions }\end{array}$ \\
\hline & & Intra-financial assets & $6.67 \%$ & Intra-financial assets & $5.7 \%$ & $\begin{array}{l}\text { Sum of lending to financial institutions and holdings of securities } \\
\text { (debt securities, commercial paper, certificates of deposit and } \\
\text { equity) issued by other financial institutions }\end{array}$ \\
\hline & \multirow[t]{4}{*}{$\begin{array}{l}\text { Loans and bonds } \\
\text { outstanding }\end{array}$} & & & Large exposures & $5.7 \%$ & $\begin{array}{l}\text { Combination of: (i) total asset exposures to the } 19 \text { largest } \\
\text { counterparties (including counterparties in derivative } \\
\text { transactions but excluding domestic sovereign debt and separate } \\
\text { account assets), and (ii) ratio of (i) to total assets (excluding } \\
\text { separate account assets), and (iii) ratio of domestic sovereign } \\
\text { exposure to its market size }\end{array}$ \\
\hline & & \multirow[t]{3}{*}{$\begin{array}{l}\text { Wholesale funding } \\
\text { ratio }\end{array}$} & \multirow[t]{3}{*}{$6.67 \%$} & Turnover & $5.7 \%$ & $\begin{array}{l}\text { Combination of: (i) ratio of total purchase of invested assets plus } \\
\text { total sale of invested assets to total assets, and (ii) ratio of total } \\
\text { sales (issuance) of funding liabilities (plus total retirement of } \\
\text { funding liabilities to total liabilities }\end{array}$ \\
\hline & & & & Level 3 assets & $5.7 \%$ & $\begin{array}{l}\text { Combination of: (i) total Level } 3 \text { assets, and (ii) ratio of (i) to sum } \\
\text { of Level 1,2, and } 3 \text { assets }\end{array}$ \\
\hline & & & & Reinsurance & $5.7 \%$ & Gross technical provisions for reinsurance assumed business \\
\hline Substitutability & $\begin{array}{l}\text { Credit default swaps } \\
\text { (CDS) outstanding }\end{array}$ & Assets under custody & $6.67 \%$ & $\begin{array}{l}\text { Premiums for specific } \\
\text { business lines }\end{array}$ & $5.0 \%$ & $\begin{array}{l}\text { Combination of direct gross premiums written and assumed } \\
\text { premiums for (i) catastrophe coverage, (ii) credit coverage (including } \\
\text { mortgage guarantee coverage, financial guarantee and export credit } \\
\text { coverage), (iii) aviation coverage, and (iv) marine coverage }\end{array}$ \\
\hline
\end{tabular}




\section{Leverage}

Liquidity risk and

Maturity mismatch

(only FSOC)
Leverage ratio

Short-term debt ratio $^{\mathrm{c}}$

ntra-group na commitments

Short-term funding ${ }^{\mathrm{d}}$

Combination of (i) intra-group commitments granted by insurance entities or the top holding company of an insurance group for the benefit of non-insurance entities of the group and intra-group commitments granted by non-insurance entities to any other entities in the group, and (ii) ratio of intra-group commitments granted by insurance entities or the top holding company of an insurance group for the benefit of non-insurance entities of the group and intra-group commitments granted by non-insurance entities to any other entities in the group to total assets

Liability liquidity $^{\mathrm{d}}$

Amount of liabilities that can be surrendered upon request within three months without economic penalty plus 50 per cent of the amount of liabilities that can be surrendered with economic penalty (such as fees or tax) lower than 20 per cent

Non-policyholder

liabilities and non-

insurance revenues from

financial activities

Derivatives trading

Derivatives trading

(excluding hedging and

replication) in economic

terms

Financial guarantees
Combination of: (i) total on-balance sheet liabilities minus all policyholder liabilities, ${ }^{\mathrm{e}}$ (ii) ratio of (i) to total balance sheet liabilities, (iii) total revenues from financial activities of noninsurance businesses, and (iv) ratio of (iii) to total revenues Gross notional amount of credit default swaps (CDS) sold

$\mathrm{na}^{\mathrm{f}} \quad$ Gross notional amount of the NTNI-related portion and the nonNTNI-related of derivatives, excluding "hedge reducing risks" and "hedge replicating risks"

6.4\% Sum of: (i) gross notional amount of debt securities (including structured finance but excluding sold CDS and surety bonds) 
insured for financial guarantee and (ii) risk-in-force for mortgage guarantee insurance (i.e. covered by all mortgage insurance policies issued)

Minimum guarantee on $\quad 6.4 \% \quad$ Total technical provisions for variable annuities and contingent

\begin{tabular}{|c|c|c|c|c|c|c|}
\hline \multirow{2}{*}{$\begin{array}{l}\text { Global activity } \\
\text { (IAIS)/ Cross- } \\
\text { jurisdictional activity } \\
\text { (BCBS) }\end{array}$} & \multirow[b]{2}{*}{ na } & \multirow[b]{2}{*}{$\begin{array}{l}\text { Cross-jurisdictional } \\
\text { claims }\end{array}$} & \multirow[b]{2}{*}{$10 \%$} & \multicolumn{2}{|l|}{ products } & \multirow{2}{*}{$\begin{array}{l}\text { guarantees } \\
\text { Sum of total revenues recognised from jurisdictions outside the } \\
\text { home country }\end{array}$} \\
\hline & & & & Foreign revenues & $2.5 \%$ & \\
\hline \multirow[t]{2}{*}{ Complexity } & na & $\begin{array}{l}\text { OTC derivatives } \\
\text { notional value }\end{array}$ & $6.67 \%$ & na & & na \\
\hline & & Level 3 assets & $6.67 \%$ & & & \\
\hline
\end{tabular}

annuities including additional technical provisions for any

variable insurace guarantees

Number of countries where a group operates through branches and/or subsidiaries outside of the home country

OTC derivatives $\quad 6.67 \%$ na

${ }^{a}$ According to Sections 113(a)(2) and (b)(2) of the Dodd-Frank Wall Street Reform and Consumer Protection Act (Dodd-Frank Act) with selection based on: (a) applicability to nonbank financial companies (NBFC) that operate in different types of financial markets and industries, (b) the meaningful initial assessment that such thresholds provide regarding the potential for a nonbank financial company to pose a threat to financial stability in diverse financial markets, and (c) the current availability of data.

bubject to review by the IAIS in future assessments.

includes "fraction of assets that are classified as Level 2 and Level 3 under applicable accounting standards ( share of hard-to-value and potentially illiquid securities)" under Step 2 of the Determination Process.

${ }^{d}$ categorised as non-traditional/non-insurance (NTNI) activity in the G-SII approach proposed by the IAIS.

eall technical provisions held for fulfilling insurance contracts.

f not considered in the application of the IAIS (2013a, b, c, d, e) methodology for the first designation of G-SIIs based on end-2011 data.

Sources: Board of the U.S. Federal Reserve System, Bank for International Settlements (BIS) and International Association of Insurance Supervisors (IAIS, 2012c and 2013b). 
sectional and time-varying risk indicators) in its assessment methodology of systemic relevance.

The implementation of the assessment methodology represents the first step towards the adoption of several policy measures associated with the designation of G-SIIs. The three policy implications flowing from the SIFI assessment involve the improvement of the regulation, supervision and resolution of SIFIs in the following areas: (i) higher loss absorbency (HLA) through additional capital charges ${ }^{55}$; (ii) more intensive supervision, stronger supervisory mandates and resources, higher supervisory expectations, enhanced reporting, including group-wide supervision; and (iii) the requirement of recovery and resolution plans (RRPs) for designated insurers, including resolution regimes and cross-border mechanisms, consistent with the key attributes on the resolution of systemic insurance groups. ${ }^{56}$ As a foundation for HLA requirements for G-SIIs, the IAIS is also developing BCR to apply to all group activities, including non-insurance subsidiaries, to be finalised by the time of the G20 Summit in $2014^{57}$ before commencing a public consultation on the implementation details for HLA by end-2015. ${ }^{58,59}$

Also national supervisors have begun to define their own criteria for the designation of non-bank SIFIs, which includes insurance companies. Changes to national insurance regulations aimed at the heightened supervision of systemically important institutions have paralleled efforts by the IAIS to define systemic risk in the insurance sector. For instance, in the United States, the FSOC $^{3}$ determines the systemic importance of nonbank financial institutions (including insurance companies) that could pose a threat to U.S. financial stability by means of a three-stage assessment process. ${ }^{60}$ The first stage ("Stage 1") establishes a triage prior to the testing for potential systemic risk, which delimits the universe of nonbank financial companies to be subject to further evaluation (as target group), based on six uniform quantitative thresholds. Subsequent testing for potential systemic risk is carried out in Stages 2 and 3 after companies that did not meet the selection criteria in Stage 1 have been excluded. In addition to the four more general aspects of systemic relevance (see Table 5), which are also included in the IAIS' G-SII methodology, the first stage of the determination process includes two additional highlevel microprudential indicators (leverage and liquidity risk/maturity mismatch) and the assessment of the level of existing regulatory scrutiny to its "determination process". The FSOC's national framework for determining systemic relevance also includes the

${ }^{55}$ HLA helps reduce the probability of distress or failure of G-SIIs and, thus, mitigates the expected impact their distress or failure by internalising some of the associated cost to the financial system and overall economy (which are otherwise externalities to the insurance group).

${ }^{56}$ FSB (2011c, 2013b).

57 IAIS (2013e).

${ }^{58}$ HLA will apply starting from January 2019 to those G-SIIs identified in November 2017, using the IAIS methodology.

${ }^{59}$ Note that the IAIS has also established a work plan for the development of comprehensive, group-wide supervisory and regulatory framework for IAIGs, including an international capital standard (ICS), which may include all (or some) of the features of the BCR.

${ }^{60}$ Such determination would be made based on whether material financial distress at the nonbank financial company, or the nature, scope, size, scale, concentration, interconnectedness, or the mix of activities of such company, could pose a threat to the financial stability of the United States (United States of America, 2010). 


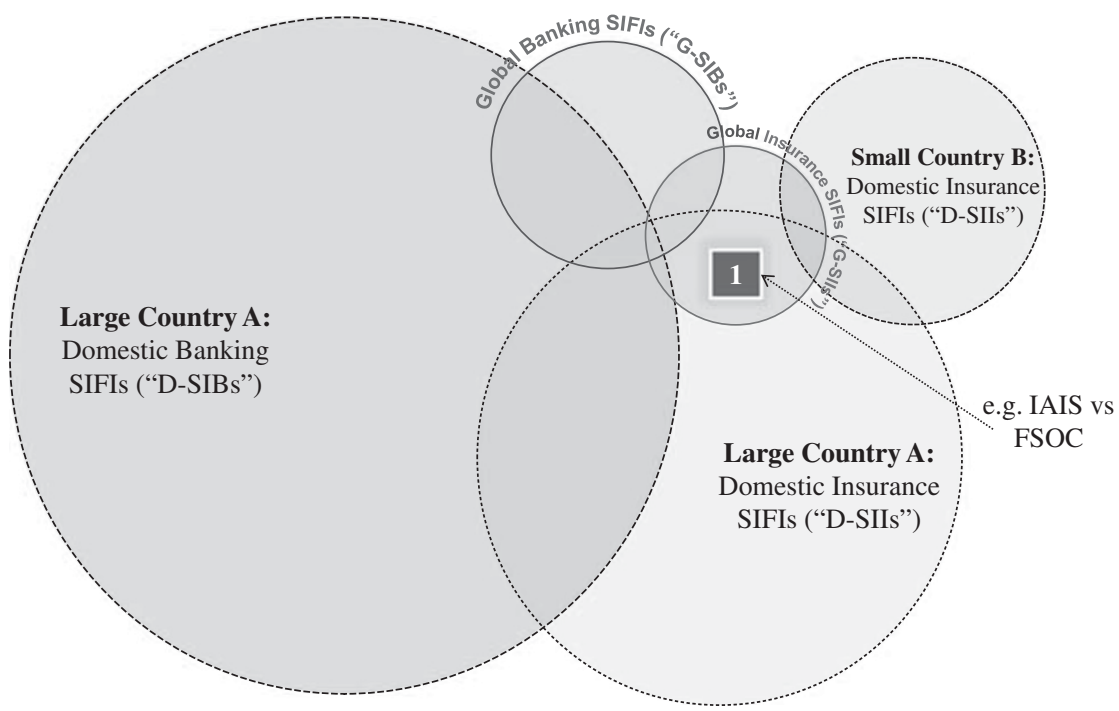

Figure 2. Potential overlaps between global and domestic SIFI methodologies.

Note: As an example, the figure illustrates the area of potential overlap between the IAIS and FSOC methodologies regarding the identification of G-SIIs that are also deemed systemically important for the financial sector in the United States. "G-SIB"=globally active, systemically important bank, "G-SII"=globally active, systemically important insurance firm and "D-SII"=domestic systemically important insurance firm.

Source: Author.

assessment of existing supervision. Such a firm-specific element (of greater "customisation") would include not only the degree to which regulatory requirements are already applicable to a particular non-bank financial institution, but also the relative effectiveness of new regulatory requirements, including enhancements to resolution regimes and the enforcement of recovery plans.

Given the wide range of different national regulations and industry structures, effective supervisory coordination is essential to a consistent and meaningful assessment of systemically relevant insurance activities both within and across national borders and different industry sectors. In particular, the identification of SIFIs is closely associated with the establishment of a suitable reference system, which defines the extent to which certain firms engage in activities that are, or could become, systemically relevant domestically or abroad. Any unintentional differences in the treatment of systemically relevant insurance firms, however, could undermine the quality and credibility of designations from different sources. ${ }^{61}$ This could happen, for instance, in cases when an international designation of an insurer is not recognised by national prudential standards in some of its most significant markets and/or systemic importance might not be significant to warrant the designation of

${ }^{61}$ The Geneva Association (2011c) also claims that having separate efforts could duplicate supervisory data requests, result in inconsistent analysis of the risks posed by individual nonbank financial companies, and distort markets' perception of these risks. 
G-SIIs but could affect financial systems of multiple countries within a region. Figure 2 illustrates how overlapping SIFI assessment methodologies of globally active insurance companies can arise, especially across different sectors, if a conglomerate includes a designated insurer but also a large bank subject to global/domestic/both SIFI designations. Attendant inconsistencies could also be compounded by the fact that some insurance groups also include banking operations that might be subject to their own macroprudential treatment -both domestically and globally.

\section{Conclusion}

In this article, we found that the current development of risk measures for the prudential assessment of G-SIIs - based on both supervisory guidance and industry level feedback-has resulted in a comprehensive assessment methodology that adequately reflects the identified scope of systemically relevant insurance activities. However, further work might be needed to enhance the consistency and effectiveness of the final version of the initial assessment methodology for G-SIIs with regard to similar efforts on a national level (as well as internationally in other sectors, such as banking, where the SIFI agenda is more advanced) in areas where adverse effects from the interaction between insurance and banking activities are most likely to manifest themselves in times of stress. The interlinkages between insurers, banks and other financial institutions may increase in the future through products, markets and organisational arrangements, which warrants enhancements to supervisory processes, combined with stronger risk management and flexible approaches to resolvability. Thus, an integrated and comprehensive systemic risk assessment supporting financial stability analysis would ideally be based on a common framework for banking, insurance and other financial activities. This would ideally be achieved by means of an in-depth cross-sectoral analysis of the three global assessment approaches (G-SIB, G-SII and NBNI G-SIFI) in areas of common risk drivers, such as derivative trading, funding sources, and intra-financial assets and liabilities.

We also examined the relevance of current diagnostics from a national perspective by investigating their impact on the (re)insurance industry in Bermuda. In reference to suggestions that liquidity management could become sources of systemic risk, we found that international insurance companies registered in Bermuda show little susceptibility to short-term funding risks and contingent liabilities from financial guarantees. Further research is needed based on an enhanced understanding of the high degree of connectedness between insurance and reinsurance firms, spillover effects from within and outside the insurance sector, and the concentration of both funding sources and potential claims impacting on the propensity of reserve depletion.

Although the progress to date suggests a practical and objective identification of systemically relevant insurance activities, the current assessment of G-SIIs is bound to unify the conjunctural dimensions of systemic risk (as a result of vulnerabilities arising from both cross-sectional and time-varying risk indicators). By incorporating supervisory judgement and validation in the G-SII assessment, the IAIS has already acknowledged the critical role of mitigating factors associated with business models and structural aspects that affect the resilience of the entire insurance sector (or parts thereof). Further work could include (i) a more nuanced assessment of substitutability and interconnectedness, with a focus on how varying channels of risk transmission that cause spillover/contagion, (ii) the statistical stability of assessment 
methodologies for the designation of G-SIIs, and (iii) the potential reconciliation of risk indicators with other assessment methodologies for G-SIBs and NBNI G-SIFIs, which would help mitigate the potential for regulatory arbitrage within insurance groups.

\section{Acknowledgements}

Research support from Lee Maximchuk is gratefully acknowledged. I thank Craig Swan and Marcelo Ramella for helpful comments and suggestions. The views expressed in this article are those of the author and should not be attributed to the BMA, the IMF, and their respective Boards of Directors.

\section{References}

Acharya, V.V., Pedersen, L.H., Philippon, T. and Richardson, M.P. (2009) Measuring systemic risk, Working Paper presented at Research Conference on Quantifying Systemic Risk, 6 November, National Bureau of Economic Research, Cambridge, MA, from www.clevelandfed.org/research/conferences/2009/11-6-2009/index.cfm, accessed 23 February 2014.

Acharya, V.V., Pedersen, L.H., Philippon, T. and Richardson, M.P. (2010) Measuring systemic risk, Federal Reserve Bank of Cleveland Working Paper 10-02, from www.clevelandfed.org/research/workpaper/2010/ wp1002.pdf, accessed 23 February 2014.

Acharya, V.V., Pedersen, L.H., Philippon, T. and Richardson, M.P. (2012) Measuring systemic risk, CEPR Discussion Paper 8824, February, from www.cepr.org/pubs/new-dps/dplist.asp?dpno=8824\&action. $x=0 \&$ action. $y=0$, accessed 23 February 2014.

Adrian, T. and Brunnermeier, M.K. (2008) CoVaR, Staff Reports 348, New York: Federal Reserve Bank of New York.

Bank for International Settlements (BIS) (2011) "Macroprudential regulation and policy", Proceedings of a joint conference organized by the BIS and the Bank of Korea in Seoul on 17-18 January 2011, Monetary and Economic Department, BIS Papers No. 60, December, Basel: Bank for International Settlements, from www.bis. org/publ/bppdf/bispap60.pdf, accessed 23 February 2014.

Basel Committee on Banking Supervision (BCBS) (2013) Global systemically important banks: updated assessment methodology and the additional loss absorbency requirement, July, Basel: Bank for International Settlements, from www.bis.org/publ/bcbs255.pdf, accessed 23 February 2014.

Basel Committee on Banking Supervision (BCBS) (2012) Models and tools for macroprudential analysis, Basel Committee Working Paper no. 21, April, Basel: Bank for International Settlements, from www.bis.org/publ/ bcbs_wp21.pdf, accessed 23 February 2014.

Basel Committee on Banking Supervision (BCBS) (2011) Global systemically important banks: Assessment methodology and the additional loss absorbency requirement, July, Basel: Bank for International Settlements, from www.bis.org/publ/bcbs201.pdf, accessed 23 February 2014.

Basel Committee on Banking Supervision (BCBS) (2009) Revisions to the Basel II market risk framework, July, Basel: Bank for International Settlements, from www.bis.org/publ/bcbs148.pdf, accessed 23 February 2014.

Bermuda Monetary Authority (BMA) (2008) Insurance (Prudential Standards) (Class 4 and Class 3B Solvency Requirement) Rules 2008 (Consolidated, excluding Schedules VII, VIII, IX and X), BR 83/2008, Bermuda Monetary Authority, Hamilton.

Bermuda Monetary Authority (BMA) (2011) Commercial Insurer's Solvency Self-Assessment (CISSA)—Instruction Handbook, 21 January, Bermuda Monetary Authority, Hamilton.

Bermuda Monetary Authority (BMA) (2012a) Enhancements to the Regulatory and Supervisory Regime for Commercial Insurers, Consultation Paper, 13 January, Bermuda Monetary Authority, Hamilton.

Bermuda Monetary Authority (BMA) (2012b) Insurance (Prudential Standards) (Class 4 and Class 3B Solvency Requirement) Amendment Rules 2012, BR 91/2012, 13 December, Bermuda Monetary Authority, Hamilton.

Billio, M., Getmansky, M., Lo, A.W. and Pelizzon, L. (2010) Econometric measures of systemic risk in the finance and insurance sectors, National Bureau of Economic Research (NBER) Working Paper no. 16223, from www. nber.org/papers/w16223, accessed 23 February 2014. 
Brownlees, C.T. and Engle, R.F. (2011) Volatility, correlation and tails for systemic risk measurement, Working Paper, 24 May, NYU Stern School of Business, from www.vleda.stern.nyu.edu/scrc/?p=2241, accessed 23 February 2014.

Brown, D.M. and Warren-Boulton, F.R. (1988) Testing the structure-competition relationship on cross-sectional firm data, Discussion Paper 88-6 (11 May), Economic Analysis Group, U.S. Department of Justice.

Chan-Lau, J. (2010) Regulatory capital charges for too-connected-to-fail institutions: A practical proposal, IMF Working Paper 10/98, Washington, DC, International Monetary Fund, from www.imf.org/external/pubs/ft/wp/ 2010/wp1098.pdf, accessed 23 February 2014.

Drehmann, M. and Tarashev, N. (2011) 'Systemic importance: Some simple indicators,' BIS Quarterly Review, pp. 25-37, Bank for International Settlements, Basel, from www.bis.org/publ/qtrpdf/r_qt1103e.pdf, accessed 23 February 2014.

Financial Stability Board (FSB) (2010) "Reducing the moral hazard posed by systemically important financial institutions", Interim Report to the G-20 Finance Ministers and Central Bank Governors, 18 June, Bank for International Settlements, Basel, from www.financialstabilityboard.org/publications/r_100627b.pdf, accessed 23 February 2014.

Financial Stability Board (FSB) (2011a) Understanding financial linkages: A common data template for global systemically important banks, Consultation Paper, 6 October, from www.financialstabilityboard.org/publications/r_111006.pdf, accessed 23 February 2014.

Financial Stability Board (FSB) (2011b) Global adherence to regulatory and supervisory standards on international cooperation and information exchange, Public Statement, 2 November, from www.financialstabilityboard.org/ publications/r_111102.pdf, accessed 23 February 2014.

Financial Stability Board (FSB) (2011c) The key attributes of effective resolution regimes for financial institutions, 4 November, Bank for International Settlements, Basel, from www.financialstabilityboard.org/publications/ r_111104cc.pdf, accessed 23 February 2014.

Financial Stability Board (FSB) (2012) Increasing the intensity and effectiveness of SIFI supervision, Progress Report to the G20 Ministers and Governors, 1 November, from www.financialstabilityboard.org/publications/ r_121031ab.pdf, accessed 23 February 2014.

Financial Stability Board (FSB) (2013a) Global Systemically Important Insurers (G-SIIs) and the Policy Measures That Will Apply to Them, Press Release, 18 July, Bank for International Settlements, Basel, from www .financialstabilityboard.org/publications/r_130718.pdf, accessed 23 February 2014.

Financial Stability Board (FSB) (2013b) Assessment Methodology for the Key Attributes of Effective Resolution Regimes for Financial Institutions, Consultative Document, 23 August, Bank for International Settlements, Basel, from www.financialstabilityboard.org/publications/r_130828.pdf, accessed 23 February 2014.

Financial Stability Board (FSB)/International Monetary Fund (IMF)/Bank for International Settlements (BIS) (2009) Guidance to Assess the Systemic Importance of Financial Institutions, Markets and Instruments: Initial Considerations, Report to the G-20 Finance Ministers and Central Bank Governors, 28 October, Bank for International Settlements, Basel, from www.financialstabilityboard.org/publications/r_091107c.pdf, accessed 23 February 2014.

Financial Stability Board (FSB)/International Monetary Fund (IMF)/Bank for International Settlements (BIS) (2011a) Macroprudential Policy Tools and Frameworks, Progress Report to G20 Finance Ministers and Central Bank Governors, 26 October, Bank for International Settlements, Basel, from www.bis.org/publ/othp17.pdf, accessed 23 February 2014.

Financial Stability Board (FSB)/International Monetary Fund (IMF)/Bank for International Settlements (BIS) (2011b) Macroprudential Policy Tools and Frameworks, Update to G20 Finance Ministers and Central Bank Governors, March, Bank for International Settlements, Basel, from www.bis.org/publ/othp13.pdf, accessed 23 February 2014.

Financial Stability Board (FSB)/International Organization of Securities Commissions (IOSCO) (2014) Assessment Methodologies for Identifying Non-Bank Non-Insurer Global Systemically Important Financial Institutions-Proposed High-Level Framework and Specific Methodologies, Consultative Document, 8 January, Bank for International Settlements, Basel, from www.financialstabilityboard.org/publications/r_140108.pdf, accessed 23 February 2014.

Financial Stability Oversight Council (FSOC) (2011) Authority to Require Supervision and Regulation of Certain Nonbank Financial Companies, Second Notice of Proposed Rulemaking and Proposed Interpretive Guidance, Federal Register, Vol. 76, No. 201 (18 October), pp. 64264-64283, from www.federalregister.gov/articles/2011/ 
10/18/2011-26783/authority-to-require-supervision-and-regulation-of-certain-nonbank-financial-companies\# p-265, accessed 23 February 2014.

Gray, D.F. and Jobst, A.A. (2010) 'New directions in financial sector and sovereign risk management', Journal of Investment Management 8(1): 23-38.

Gray, D.F. and Jobst, A.A. (2011a) 'Systemic contingent claims analysis-A model approach to systemic risk', in J.R. LaBrosse, R. Olivares-Caminal and D. Singh (eds.) Managing Risk in the Financial System, London: Edward Elgar, pp. 93-110.

Gray, D.F. and Jobst, A.A. (2011b) "Modelling systemic financial sector and sovereign risk", Sveriges Riksbank Economic Review, No. 2, pp. 68-106, from www.riksbank.se/upload/Rapporter/2011/POV_2/er_2011_2.pdf, accessed 23 February 2014.

Hirschman, A.O. (1964) 'The paternity of an index', American Economic Review 54(5): 761.

Houben, A. and Teunissen, M. (2011) 'The systemicness of insurance companies: Cross-border aspects and policy implications', in P.M. Liedtke and J. Monkiewicz (eds.) The Future of Insurance Regulation and Supervision-A Global Perspective, London: Palgrave Macmillan, pp. 246-69.

Huang, X., Zhou, H. and Zhu, H. (2009) 'A framework for assessing the systemic risk of major financial institutions', Journal of Banking and Finance 33(11): 2036-49.

Huang, X., Zhou, H. and Zhu, H. (2010) Assessing the systemic risk of a heterogeneous portfolio of banks during the recent financial crisis, Working Paper no. 296, Bank for International Settlements, Basel, from www.bis.org/ publ/work296.pdf, accessed 23 February 2014.

International Association of Insurance Supervisors (IAIS) (2009) Systemic risk and the insurance sector, 25 October, Bank for International Settlements, Basel, from www.iaisweb.org/_temp/Note_on_systemic_ risk_and_the_insurance_sector.pdf, accessed 23 February 2014.

International Association of Insurance Supervisors (IAIS) (2010a) Macroprudential Surveillance and (Re) Insurance, Global Reinsurance Market Report, Mid-year Edition, 26 August, Bank for International Settlements, Basel, from www.iaisweb.org/view/element_href.cfm?src=1/9926.pdf, accessed 23 February 2014.

International Association of Insurance Supervisors (IAIS) (2010b) Position Statement on Key Financial Stability Issues, 4 June, Bank for International Settlements, Basel, from www.iaisweb.org/_temp/IAIS_Position_Statement_on_Key_Financial_Stability_Issues.pdf, accessed 23 February 2014.

International Association of Insurance Supervisors (IAIS) (2011a) Insurance and Financial Stability, November, Bank for International Settlements, Basel, from www.iaisweb.org/view/element_href.cfm?src=1/13348.pdf, accessed 23 February 2014.

International Association of Insurance Supervisors (IAIS) (2011b) Insurance Core Principles, Standards, Guidance and Assessment Methodology, 1 October, Bank for International Settlements, Basel, pp. 357-360, from www .iaisweb.org/_temp/Insurance_Core_Principles_Standards_Guidance_and_Assessment_Methodology__ October_2011.pdf, accessed 23 February 2014.

International Association of Insurance Supervisors (IAIS) (2011c) Global Reinsurance Market Report, 23 December, Bank for International Settlements, Basel, from www.iaisweb.org/Global-Reinsurance-MarketReport-GRMR-538, accessed 23 February 2014.

International Association of Insurance Supervisors (IAIS) (2012a) Global Systematically Important Insurers: Proposed Policy Measures, Public Consultation Document, 17 October, Bank for International Settlements, Basel, from www.iaisweb.org/view/element_href.cfm?src=1/16023.pdf, accessed 23 February 2014.

International Association of Insurance Supervisors (IAIS) (2012b) Reinsurance and Financial Stability, 19 July, Bank for International Settlements, Basel, from www.iaisweb.org/view/element_href.cfm?src=1/16023.pdf, accessed 23 February 2014.

International Association of Insurance Supervisors (IAIS) (2012c) Global Systemically Important Insurers: Proposed Assessment Methodology, Public Consultation Document, 31 May, Bank for International Settlements, Basel, from www.iaisweb.org/view/element_href.cfm?src=1/15384.pdf, accessed 23 February 2014.

International Association of Insurance Supervisors (IAIS) (2013a) IAIS Releases Global Systemically Important Insurers Assessment Methodology and Policy Measures, Macroprudential Policy and Surveillance Framework, Press Release, 18 July, Bank for International Settlements, Basel, from www.iaisweb.org/db/content/1/19152 .pdf, accessed 23 February 2014. 
International Association of Insurance Supervisors (IAIS) (2013b) Global Systemically Important Insurers: Final Initial Assessment Methodology, 18 July, Bank for International Settlements, Basel, from www.iaisweb.org/view/ element_href.cfm?src=1/19151.pdf, accessed 23 February 2014.

International Association of Insurance Supervisors (IAIS) (2013c) Global Systemically Important Insurers: Final Policy Measures, Press Release, 18 July, Bank for International Settlements, Basel, from www.iaisweb.org/view/ element_href.cfm? src=1/19150.pdf, accessed 23 February 2014.

International Association of Insurance Supervisors (IAIS) (2013d) Macroprudential Policy and Surveillance in Insurance, Macroprudential Surveillance and Policy Subcommittee (MPSSC), 18 July, Bank for International Settlements, Basel, from www.iaisweb.org/view/element_href.cfm?src=1/19149.pdf, accessed 23 February 2014.

International Association of Insurance Supervisors (IAIS) (2013e) Basic Capital Requirements: Proposal for Basic Capital Requirements (BCR) for Global Systemically Important Insurers (G-SIIs), Public Consultation, 20 December, Bank for International Settlements, Basel, from www.iaisweb.org/News/Consultations/BasicCapital-Requirement-1141, accessed 23 February 2014.

International Monetary Fund (IMF) (2010) Integrating Stability Assessments Under the Financial Sector Assessment Program into Article IV Surveillance: Background Material, Monetary and Capital Markets Department, 27 August, International Monetary Fund, Washington, DC, pp. 3-15, from www.imf.org/external/np/pp/eng/ 2010/082710a.pdf, accessed 23 February 2014.

International Monetary Fund (IMF) (2011a) Toward Operationalizing Macroprudential Policies: When to Act? Global Financial Stability Report, Chapter 3, September, World Economic and Financial Surveys, Washington, DC: International Monetary Fund, from www.imf.org/external/pubs/ft/gfsr/2011/02/pdf/ch3.pdf, accessed 23 February 2014.

International Monetary Fund (IMF) (2011b) 'Macroprudential policy: An organizing framework', Monetary and Capital Markets, 14 March, International Monetary Fund, Washington, DC, from www.imf.org/external/np/pp/ eng/2011/031411.pdf, accessed 23 February 2014.

International Monetary Fund (IMF) (2013) Key Aspects of Macroprudential Policy, Board Paper, 10 June, International Monetary Fund, Washington, DC, from www.imf.org/external/np/pp/eng/2013/061013b.pdf.

Jobst, A.A. (2013) 'Multivariate dependence of implied volatilities from equity options as measure of systemic risk', International Review of Financial Analysis 28(June): 112-29.

Jobst, A.A. and Gray, D.F. (2013) Systemic contingent claims analysis-Estimating market-implied systemic risk, IMF Working Paper No. 13/54, International Monetary Fund, Washington, DC, from www.imf.org/external/ pubs/ft/wp/2013/wp1354.pdf, accessed 23 February 2014.

Jones, R.C., Griffith, J.E., Iten, J. and Vine, M.J. (2013) "Global insurance key risks and credit trends dominated by low interest rates and regulation issues," Ratings Direct, Standard and Poor's Rating Services, RatingsDirect on the Global Credit Portal, 21 January, from www.standardandpoors.com/spf/upload/Ratings_EMEA/2013-0121_GlobalInsuranceKeyRisksAndCreditTrends.pdf, accessed 23 February 2014.

Lehmann, R.J. and Lehrer, E. (2011) Comments on Report to Congress on How to Modernize and Improve the System of Insurance Regulation in the United States, Center on Finance, Insurance and Real Estate, 29 November, The Heartland Institute, Washington, DC, from www.heartland.org/sites/default/files/Heartland_ Comments_to_Federal_Insurance_Office.pdf, accessed 23 February 2014.

Liedtke, P.M. (2011) Assessment of systemic risk indicators in the insurance sector, Working Paper series of The Geneva Association, Etudes et Dossiers, No. 377 (presented at the $13^{\text {th }}$ Meeting of The Geneva Association's Amsterdam Circle of Chief Economists (17-18 February) and the $7.5^{\text {th }}$ International Liability Regimes Conference of The Geneva Association, 17 June, August, from www.genevaassociation.org/PDF/ Working_paper_series/1_GA_E\&D_377_05_LIEDTKE_Finance,Systemic_risk,SIFIs.pdf, accessed 23 February 2014.

The Geneva Association (2010a) Systemic Risk in Insurance-An Analysis of Insurance and Financial Stability, Special Report of the Geneva Association Systemic Risk Working Group, March, Geneva: The International Association for the Study of Insurance Economics, from www.genevaassociation.org/portals/0/Geneva Association_Systemic_risk_in_Insurance_Report_March2010.pdf, accessed 23 February 2014.

The Geneva Association (2010b) Key Financial Stability Issues in Insurance-An Account of the Geneva Association Ongoing Dialogue on Systemic Risk with Regulators and Policy-Makers, July, The International Association for the Study of Insurance Economics, Geneva, from www.genevaassociation.org/pdf/ 
470

BookandMonographs/Geneva_Association_Key_Financial_Stability_Issues_in_Insurance_July2010.pdf, accessed 23 February 2014.

The Geneva Association (2011a) Assessment of Systemic Risk Indicators in the Insurance Sector, IAIS Technical Committee Observer Hearing, 17 February, The International Association for the Study of Insurance Economics, Geneva, from www.genevaassociation.org/pdf/News/GA_Presentation_IAIS_Hearing_17Feb2011.pdf, accessed 23 February 2014.

The Geneva Association (2011b) Considerations for Identifying Systemically Important Financial Institutions in Insurance: A Contribution to the Financial Stability Board and International Association of Insurance Supervisors' Discussions, April, The International Association for the Study of Insurance Economics, Geneva, from www.genevaassociation.org/PDF/BookandMonographs/GA2011-Considerations_for_Identifying_SIFIs_in_Insurance.pdf, accessed 23 February 2014.

The Geneva Association (2011c) Expert Submission to the Financial Stability Oversight Council (FSOC) on Authority to Require Supervision and Regulation of Certain Nonbank Financial Companies, Press Release 16-1, 19 December, The International Association for the Study of Insurance Economics, Geneva, from www.genevaassociation.org/PDF/General_Information/GA2011-PR-16-11.pdf, accessed 23 February 2014.

The Geneva Association (2012a) Letter to the Federal Reserve Board on Enhanced Prudential Standards and Early Remediation Requirements for Covered Companies, 30 April, The International Association for the Study of Insurance Economics, Geneva, from www.genevaassociation.org/LinkClick.aspx?fileticket=977rAi9tgyg\% $3 d \&$ tabid $=67$, accessed 23 February 2014.

The Geneva Association (2012b) Cross Industry Analysis: 28 G-SIBs vs. 28 Insurers Comparison of Systemic Risk Indicators, 11 December, The International Association for the Study of Insurance Economics, Geneva, from www.genevaassociation.org/pdf/News/GA2012_Benchmark_Study.pdf, accessed 23 February 2014.

United States of America (2010) Public Law 111-203-Dodd-Frank Wall Street Reform and Consumer Protection Act, Bill Number H.R. 4173, 21 July, from http://www.gpo.gov/fdsys/pkg/PLAW-111publ203/content-detail. html, accessed 23 February 2014.

Weistroffer, Christian (2011) Identifying Systemically Important Financial Institutions (SIFIs), International Topics-Current Issues, Deutsche Bank Research, 11 August, from www.ideas.repec.org/p/ess/wpaper/id4383 .html, accessed 23 February 2014.

\section{About the Author}

Andreas A. Jobst is a senior economist at the International Monetary Fund (IMF) in Washington, DC. The article was completed when he was the Chief Economist of the Bermuda Monetary Authority (BMA) between 2011 and 2014. Until end-2013, he was also heavily involved in both the Financial Stability Committee (FSC) and the Macroprudential Policy and Surveillance Subcommittee (MPSSC) of the International Association of Insurance Supervisors (IAIS). Before his appointment at the BMA, he had already spent more than 6 years as mid-career economist at the IMF where he was co-author of the Global Financial Stability Report (GFSR). 